\title{
Aplikasi kascing pada sistem minapadi di Kelompok Sipakamase Desa Gentung Kabupaten Pangkep
}

\author{
Ratnawaty Fadilah ${ }^{1}$, Andi Sukainah ${ }^{2}$, Reski Praja Putra ${ }^{3}$ \\ ${ }^{1,2,3}$ Fakultas Teknik, Universitas Negeri Makassar
}

\begin{abstract}
The purpose of this PKM is to provide a solution of the problems facing counterparts cultivator of milkfish and Tilapia is Sipakamase Group in Gentung Village, Labbakkang Sub District, Pangkep District. The main problems faced by fish farmers in the district are the high use of inorganic fertilizer, the more of low quantity of produce, often the attack disease and decreacing quality of ponds. The target to be achieved is to give new technology innovation on the use of vermi-compost on the cultivation of milkfish and Tilapia by applying in minapadi system. This application is expected to used as a solution of the problems facing fish farmers. The method done begins with conducting observations on ponds, plan and design of minapadi system, application of vermicompost in the pond. The result of PKM are the rise of their knowledge and skill in organic farming system that capable to reduce the cost of the production and increase pond productivity.
\end{abstract}

Keywords: fishpond, minapadi system, vermin-compost, mol, environmental friendly

\section{PENDAHULUAN}

Bandeng (Chanos chanos Forsskal) merupakan salah satu komoditas potensial Sulawesi Selatan yang sangat digemari masyarakat karena memiliki cita rasa gurih, nilai gizi tinggi dan harga terjangkau. Setiap tahun permintaan ikan bandeng selalu mengalami peningkatan, baik untuk konsumsi lokal maupun untuk ekspor (Syamsuddin, 2010). Produksi bandeng Indonesia pada tahun 2012 sebesar 482.930 ton (Anwar, 2014). Jumlah ini masih jauh dari jumlah permintaan dunia akan produk tambak termasuk bandeng yang mencapai 80 juta ton tahun 2015 . Kebutuhan ini akan semakin meningkat seiring peningkatan jumlah penduduk.

Selain untuk konsumsi, bandeng juga sering digunakan sebagai bahan baku utama untuk umpan bagi industri perikanan tuna. Permintaan akan bandeng untuk konsumsi domestik maupun ekspor yang cenderung meningkat merupakan peluang usaha yang positif. Namun, peluang tersebut belum dapat terpenuhi karena beberapa kendala. Beberapa kendala tersebut diantaranya: makin tingginya biaya produksi akibat kebutuhan pupuk, pestisida, pakan meningkat, waktu budidaya bandeng semakin panjang, kualitas air menurun, musim tidak menentu akibat terjadi perubahan iklim dan sering terjadi kematian massal bandeng.

Kendala terbesar budidaya bandeng yang dihadapi petambak saat ini adalah sering terjadi kematian bandeng secara massal dan mendadak. Kematian massal bandeng sudah terjadi di berbagai tempat di Sulawesi Selatan sejak tahun 2010.

Beberapa kendala yang sering dihadapi bagi pengelola tambak di lahan tanah sulfat masam yaitu tingkat kemasaman tanah yang sangat tinggi $(\mathrm{pH}<3,5)$, adanya senyawa pirit, konsentrasi $\mathrm{Fe}^{2+}$, $\mathrm{SO}_{4}^{-}$tinggi, dan kurang tersedia hara terutama fosfor. Lahan semacam ini bila digunakan menjadi lahan tambak dan tanahnya digunakan untuk pembuatan pematang diperkirakan tambaknya tidak berproduksi (gagal panen), sehingga banyak pembudidaya yang mengalami kerugian karena kurang pengetahuan mengenai kondisi tanahnya dan lambat laun lahan ini menjadi lahan tidur (bongkor) karena kurang termanfaatkan.

Hasil penelitian Blue Forests penyebab seringnya terjadi kematian massal bandeng di tambak yaitu tingginya dosis penggunaan pupuk anorganik yang digunakan para petambak. Hal ini dapat dilihat dengan kondisi lumpur tambak yang 
semakin berbau busuk, terdapat lapisan seperti semen di bagian atas lumpur tambak.

Pupuk yang paling sering digunakan oleh petambak adalah pupuk urea dan TSP. Penggunaan berbagai jenis pupuk, pestisida, dan pakan di tambak awalnya hanya mengikuti penggunaan pupuk, pestisida, dan pakan yang sering digunakan di pertanian dengan tujuan mempercepat pertumbuhan kelekap dalam tambak sebagai pakan bandeng (Rangka \& Asaad, 2010).

Berbeda dengan pupuk organik, penggunaan pupuk anorganik secara berlebihan pada tambak akan mengakibatkan lumpur tambak menjadi berbau busuk, merusak sifat fisik, kimia dan biologi tanah. Selain itu dosis pupuk anorganik yang digunakan terus meningkat, sehingga meningkatkan sehingga menambah biaya produksi. Penggunaan pupuk anorganik tidak hanya merusak tanah tapi juga memberi dampak pada kesehatan udang atau ikan yang dibudidayakan.

\section{METODE PELAKSANAAN}

Pelaksanaan PKM terdiri dari beberapa kegiatan diantaranya: survey lokasi mitra sekaligus diskusi dengan anggota kelompok terkait permasalahan yang dihadapi oleh Kelompok pembudidaya tambak dan rencana solusi yang akan dilakukan. Dalam tahapan ini hasil yang diperoleh adalah daftar permasalahan atau kesulitan yang dihadapi oleh mitra dalam berbudidaya. Untuk aspek produksi, solusi yang akan diberikan adalah penerapan system mina padi yang menggabungkan pemeliharaan ikan dengan budidaya padi di lahan tambak yang terendam banjir pada musim hujan.

Kegiatan selanjutnya adalah pelatihan pembuatan pupuk kompos cacing (kascing) dan mikroorganisme lokal (mol) sebagai pengurai bahan organik. Kegiatan ini menghasilkan peningkatan pengetahuan dan keterampilan petambak untuk mampu memproduksi pupuk kompos berbahan baku bahan organik yang berkualitas tinggi, aman bagi lingkungan dan menjamin keberlanjutan.

Metode pendekatan yang dilakukan yaitu menggunakan teknik pendidikan orang dewasa yang berbasis pengalaman. Kegiatan yang akan dilakukan adalah pendampingan secara intensif pada kelompok masyarakat tentang bagaimana memproduksi mol dan kompos cacing yang baik untuk sistem mina padi yang akan diterapkan. Selain pendampingan terkait teknis pembuatan mol dan kompos, pendekatan lain yang dilakukan adalah membangun diskusi mendalam tentang analisa budidaya minapadi, dampak penggunaan pupuk organik dan anorganik.

Program Kemitraan Masyarakat (PKM) bermitra dengan Kelompok Pembudidaya tambak Kelompok Sipakamase Desa Gentung, Kecamatan Labbakkang Kabupaten Pangkep.

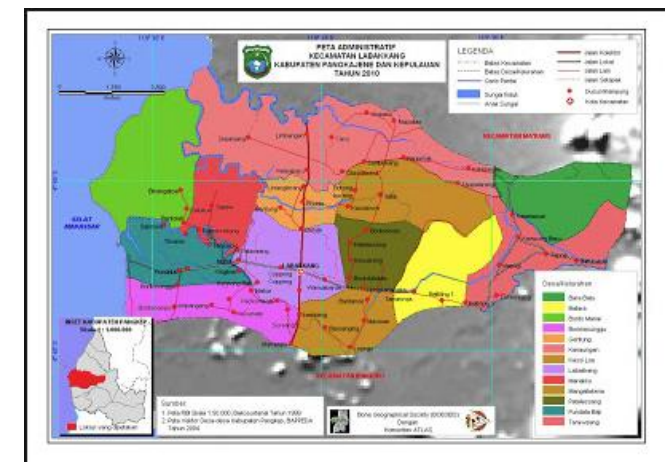

Gambar 1. Peta Desa Gentung di Kecamatan Labbakkang Kabupatem Pangkep

Permasalahan yang dihadapi Mitra:

1. Penurunan produktivitas tambak udang dan bandeng.

2. Penggunaan pupuk kimia anorganik yang tidak terkontrol.

3. Penggunaan pestisida yang berlebihan.

4. Ketergantungan terhadap pakan sangat tinggi.

5. Biaya produksi yang makin tinggi.

6. Waktu budidaya yang makin lama karena bandeng dan udang terhambat pertumbuhannya.

7. Kualitas tanah tambak yang semakin rusak akibat defisiensi nutrisi dan penggunaan bahan kimia yang merusak.

8. Sering terjadi kematian udang dan bandeng.

9. Serangan virus dan penyakit yang makin intensif.

10. Kehilangan mangrove.

11.Pengolahan tanah tidak optimal.

12.Banjir pada musim penghujan.

13.Pengelolaan tambak sangat sederhana. 


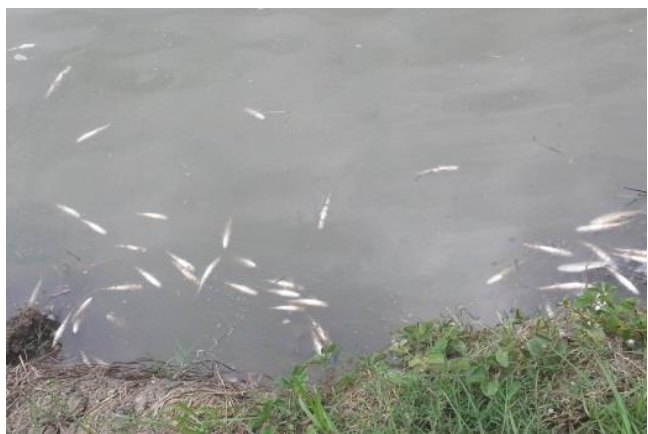

Gambar 2. Kematian bandeng di tambak

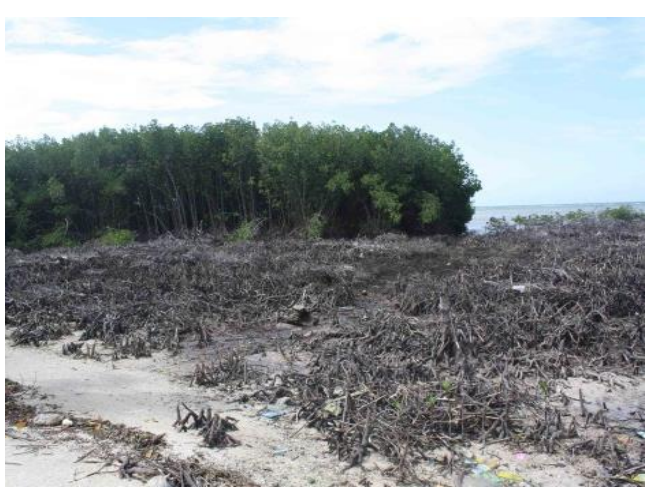

Gambar 3. Kerusakan mangrove

Pemahaman petambak tentang penggunaan pupuk anorganik masih sangat rendah. Hal ini dibuktikan dengan beragamnya jumlah dosis pupuk yang sering diaplikasikan pada tambak tergantung keinginan dan kemampuan ekonomi petambak. Menurut Dinas Perikanan dan Kelautan Kabupaten Pangkep, di wilayah Kabupaten Pangkep, jumlah dosis Urea yang digunakan sekitar $250 \mathrm{~kg}$ hingga 1 ton urea/ha. Dosis ini pada dasarnya sudah diluar dari ambang batas penggunaan pupuk. Kelebihan penggunaan pupuk anorganik akan membawa dampak negatif pada tambak dan bandeng yang dihasilkan.

Selain itu, penurunan produktivitas tambak sanagt dipengaruhi oloeh kehilangan mangrove di wilayah tersebut. Ekosistem mangrove memiliki produktivitas yang tinggi dalam hal menyediakan makanan berlimpah bagi berbagai jenis hewan laut dan juga sebagai tempat berkembang biak, memijah dan membesarkan anak bagi beberapa jenis ikan, kerang, kepiting dan udang. Secara tidak langsung kehidupan manusia tergantung pada keberadaan ekosistem mangrove pada wilayah pesisir.

Kerusakan pantai dan lahan mangrove di kawasan pesisir pantai sangat mempengaruhi penurunan kualitas lingkungan wilayah pesisir. Mangrove memiliki peran penting dalam menjaga kualitas air dan memfilter air dari bahan cemaran sebelum masuk ke tambak.

\section{HASIL DAN PEMBAHASAN}

\section{A. Pengumpulan Informasi Mengenai Sistem Budidaya Tambak di Kelompok Sipakamase}

Tahap awal yang dilakukan adalah observasi mengenai sistem budidaya yang diterapkan oleh petambak. Secara umum sistem yang diterapkan adalah pengolahan tambak secara tradisional yang sangat tergantung pada penggunaan pupuk dan pestisida kimia. Data yang diperoleh pada kegiatan observasi dapat dilihat pada Tabel 1.

Tabel 1. Data penggunaan pupuk dan pestisida

\begin{tabular}{cll}
\hline No. & $\begin{array}{c}\text { Nama } \\
\text { Petambak }\end{array}$ & \multicolumn{1}{c}{$\begin{array}{c}\text { Riwayat Penggunaan Pupuk } \\
\text { dan pakan }\end{array}$} \\
\hline 1 & Saharuddin & $\begin{array}{l}\text { Urea, Akodan, Saponin, decis, } \\
\text { mie kadaluarsa }\end{array}$ \\
\hline 2 & Cammeng & $\begin{array}{l}\text { Urea, TSP, Akodan, Decis, } \\
\text { Saponin, mie, roti }\end{array}$ \\
\hline 3 & Usman & Urea, NPK, Racun, akodan, mie \\
\hline 4 & Hasanuddin & $\begin{array}{l}\text { Petroganik, urea, TSP, racun, } \\
\text { saponin, mie, kacang }\end{array}$ \\
\hline 5 & Laega & Urea, saponin, decis, akodan \\
\hline 6 & Syamsuddin & $\begin{array}{l}\text { TSP, erea, NPK, akodan, racun, } \\
\text { mie, biskuit }\end{array}$ \\
\hline 7 & Saleng & $\begin{array}{l}\text { Urea, NPK, Racun, akodan, mie, } \\
\text { roti }\end{array}$ \\
\hline 8 & H. Syamsu & $\begin{array}{l}\text { Urea, NPK, TSP, Petroganik, } \\
\text { Decis, Saponin }\end{array}$ \\
\hline 9 & Maudu & $\begin{array}{l}\text { Urea, Akodan, decis, racun, } \\
\text { akodan,mie kadaluarsa }\end{array}$ \\
\hline 10 & Amran & $\begin{array}{l}\text { Urea, racun, minyak tanah, } \\
\text { saponin, mie }\end{array}$ \\
\hline
\end{tabular}

Berdasarkan data dan informasi yang dikumpulkan pada tahap observasi, yang mana petambak di kelompok Sipakamase 95\% menggunakan pupuk kimia anorganik dalam usaha budidaya tambaknya. Penggunaan pupuk kimia dan pestisida kimia terus mengalami penigkatan namun berbanding terbalik dengan produksi. 


\section{B. Pelatihan Pembuatan dan Aplikasi Kascing pada Tambak}

Salah satu pemicu penurunan produksi tambak adalah semakin menurunnya kualitas tanah tambak akibat waktu budidaya yang sudah berlangsung lama sejak tahun 1980. Selain itu penggunaan pupuk kimia anorganik mempengaruhi sifat fisik dan kimia tanah yang akhirnya menimbulkan kerusakan tanah tambak. Hasil penelitian Balai Perikanan Budidaya Air Payau (BPBAP) Takalar pada tahun 2012 yang menunjukkan terjadi akumulasi bahan anorganik di tambak yang memperngaruhi sistem budidaya tambak. Dan merekomendasikan penggunaan bahan organik pada tambak. Berdasarkan hal tersebut di atas maka dilakukan pelatihan pembuatan kompos dari cacing.

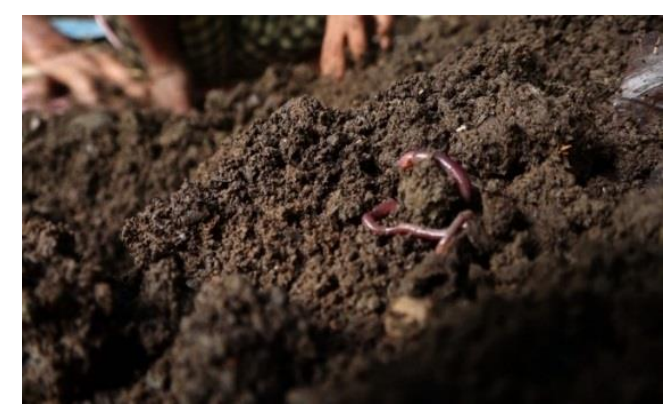

Gambar 4. Kompos cacing (Kascing)

Penggunaan pupuk kompos terbukti mampu meningkatkan kualitas tanah tambak. Kascing mengandung zat perangsang tumbuh seperti giberlin, sitokinin, ausin dan unsur hara $\mathrm{N}, \mathrm{P}, \mathrm{K}$, $\mathrm{Mg}, \mathrm{Ca}$, serta bakteri azotobacter sp yang merupakan bakteri penambat $\mathrm{N}$ non simboltik yang akan membantu memperkaya unsur $\mathrm{N}$ yang dibutuhkan oleh tanaman. Kascing juga mengandung berbagai unsur hara mikro yang dibutuhkan tanaman seperti $\mathrm{Fe}, \mathrm{Mn}, \mathrm{Zn}$, Bo dan Mo.

\section{Aplikasi Kascing pada Tambak Minapadi}

Penurunan produktivitas tambak sudah terjadi sejak akhir tahun 1998 hingga saat ini. Usaha tambak terus mengalami penurunan kualitas dan kuantitas. Pada musim penghujan, beberapa tambak yang memiliki pematang rendah tidak dapat digunakan untuk budidaya ikan. Sehingga diperlukan alternatif agar tambaknya tetap dapat menghasilkan. Kegiatan lain yang dilakukan adalah aplikasi kascing pada tambak yang diujicoba dengan sistem minapadi.

Sistem minapadi adalah sistem budidaya yang menerapkan strategi pertanian dari sistem monokultur ke sistem diversifikasi pertanian. Minapadi mengkombinasikan budidaya padi dan ikan dalam satu tambak. Sistem minapadi mampu meningkatkan keragaman hasil perikanan dan pendapatan petambak. Selain itu sistem minapadi juga dapat meningkatkan kesuburan tanah dan air juga dapat mengurangi serangan hama dan penyakit pada tanaman padi.

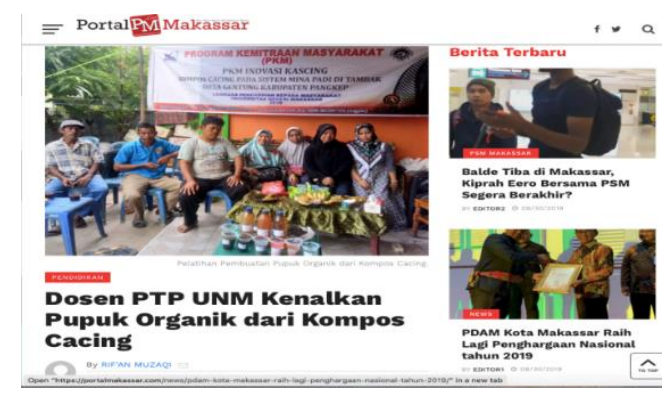

Gambar 5. Kegiatan PKM di kelompok sipakamase

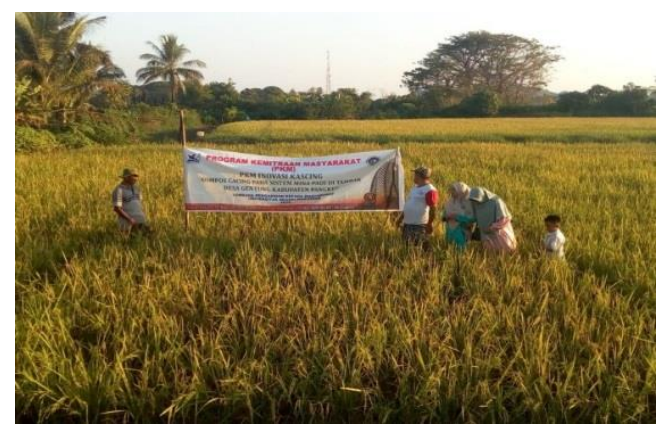

Gambar 6. Ssitem manipadi di tambak desa Gentung

Sistem minapadi memiliki keuntungan dimana sistem ini dapat menyediakan pangan sumber karbohidrat, sekaligus menyediakan pangan sumber protein sehingga sangat sesuai untuk meningkatkan mutu makanan penduduk di pesisir. Penerapan teknologi tepat guna memberi keuntungan yaitu akan optimalisasi sumber daya lokal sehingga dapat mengurangi pengeluaran biaya produksi dan membangun kemandirian petambak.

\section{KESIMPULAN}


Hasil pelaksanaan Program Kemitraan Masyarakat dapat ditarik kesimpulan:

1. Aplikasi kompos cacing pada sistem minapadi mampu meningkatnya pengetahuan dan keterampilan petambak dalam membuat kompos cacing.

2. Terimplementasinya aplikasi kompos cacing pada sistem minapadi di tambak Desa Gentung Kabupaten Pangkep. Penerapan kompos cacing di tambak mampu menekan biaya produksi dan meningkatkan produktivitas tambak

\section{UCAPAN TERIMA KASIH}

Ucapan terima kasih disampaikan kepada Universitas Negeri Makassar yang telah memberikan hibah. Selanjutnya ucapan terima kasih disampaikan pula kepada Rektor dan Ketua
Lembaga Pengabdian Kepada Masyarakat UNM dan Kelompok Sipakamase dan Pemerintah Desa Gentung Kecamatan Labbakkang Kabupaten Pangkep Provinsi Sulawesi Selatan, yang telah memberi fasilitas, melakukan monitoring, dan meng-evaluasi kegiatan PKM hingga selesai.

\section{DAFTAR PUSTAKA}

Anwar, Chairil. 2014. Budidaya Ikan Bandeng (Chanos chanos) pada tambak ramah lingkungan. WWF Indonesia, Jakarta.

Rangka, N. A dan I. J. Asaad. 2010. Teknologi Budidaya Ikan Bandeng di Sulawesi Selatan. Prosiding Forum Inovasi Teknologi Aquaculture.

Syamsuddin, R. 2010. Sektor Perikanan Kawasan Indonesia Timur: Potensi, Permasalahan, dan Prospek. PT Perca, Jakarta. 